\title{
The Proposed Employee Free Choice Act: Strengthening The American Middle Class Or Tyranny By Union Organizations?

\author{
Richard Trotter, University of Baltimore, USA
}

\begin{abstract}
Presently before Congress is the proposal Employee Free Choice Act which would amend the National Labor Relations Act in the following ways:

(1) By requiring employers to recognize a union after a majority of employees sign authorization cards for union representation. Under the present system the employer is not required to recognize the union on the basis of authorization cards and can ask for a secret ballot election conducted by the National Labor Relations Board.

(2) Provide for mediation and arbitration if the parties are not successful in negotiating a first contract after the union is recognized. The present system does not provide for mandatory impasse resolution procedures for first contract negotiations.

(3) Authorize civil fines of up to $\$ 20,000$ per violation and awards to employees discharged for union activities of "three times back pay." Under the present law fines for violating the law are much smaller than the proposed legislation and workers can only get back pay, les than what they earned from other employment, during the period after they were wrongfully discharged.

Over the past thirty years there has been an increasing inequality of income distribution in the United States and an erosion of employer provided health care and pension benefits for non-union as well as union employees. Strengthening the ability of workers to unionize will have a spillover impact on the members of the middle class, non-union and union in terms enhancing real income gains, as well as preserving and enhancing existing pension benefits and health care.
\end{abstract}

Keywords: The Employee Free Choice Act makes it easier for unions to organize and provides for impasse resolution procedures for first contract negotiations and increased penalties for employers who wrongfully discharge workers for union activity.

\section{INTRODUCTION}

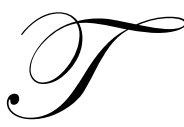

he U.S. House of Representatives passed The Employee Free Choice Act, but the bill was stalled in the Senate on June 26, 2007 after failure to reach the 60 votes needed to cut off debate. The tally, which was 51-48, was strongly divided along party lines.(1)

On February 8, 2007, the U.S. House of Representatives Subcommittee on Health, Employment, Labor and Pensions held a hearing on Strengthening America's Middle Class Through the Employee Free Choice Act. On March 27, 2007, the U. S. Senate Committee on Health, Education, Labor, and Pensions held hearings on the Employee Free Choice Act and the larger issues of the right of workers to organize, economic freedom and the middle class squeeze.

The legislation would be the most significant federal labor law revision in decades. Proponents argue that by enabling employees to form a union without the formality of secret ballot elections, the Bill will provide greater protection against what some believe to be coercive employer conduct during union organizing. Opponents argue that if workers are unable to vote by secret ballot to select a union to represent them, they will be subject to undue pressure from unions (and from some employers) and the failure of unions to increase membership is due to the 
decreasing benefits of unionization rather than to employer misconduct. Other notable provisions include, mandatory federal mediation at the request of either party if a newly organized company and the union cannot agree on the first contract, with the contract terms being determined by an arbitrator if an agreement is not reached in mediation.

Specifically, the Bill would amend the National Labor Relations Act by requiring the following:

Certification on the basis of majority sign-up: Would provide for certification of a union as the bargaining representative of a unit of employees if the National Labor Relations Board (NLRB) finds that a majority of those employees have signed authorization cards designating the union as its bargaining representative. In addition, it would require the board to develop authorization language and procedures for establishing the validity of signed authorizations.

At the time the bill was introduced, a group of workers hoping to unionize were required to sign authorization cards indicating that fact. Once $30 \%$ of potential members signed the cards, the National Labor Relations Board (NLRB) would then schedule a supervised election in which members would vote on whether or not to unionize. Even in cases where large majorities of potential members expressed a desire to unionize, the election process could still be ordered.

A company had the legal ability to allow its workers to have union representation (without going through the NLRB) if a majority of potential members supported unionization. The Employee Free Choice Act would make this recognition mandatory, taking away a company's ability to force a majority of potential members to go through the NLRB election process.

(2) First-contract mediation and arbitration: Would declare that if an employer and a union are engaged in bargaining for their first contract and are unable to reach an agreement within 90 days, either party may refer the dispute to the Federal Mediation and Conciliation Service (FMCS) for mediation. If the FMCS was then unable to bring the parties to agreement after 30 days of mediation, the dispute would be referred to arbitration, and the results of the arbitration would be binding on the parties for two years. These time limits could be extended, however, if both parties agreed to do so.

Stronger penalties for violations while employees are attempting to form a union or attain a first contract: Violators of the National Labor Relations Act would now face the following punishments.

- Civil fines of up to $\$ 20,000$ per violation against employers found to have willfully or repeatedly violated employees' rights during an organizing campaign or first-contract drive.

- An increase in the amount an employer is required to pay when an employee is discharged or discriminated against during an organizing campaign or first-contract drive to "three times back pay."(2)

\section{ARGUMENTS IN FAVOR OF THE BILL}

Strong arguments have been presented in favor of and against the Bill. Proponents of the Bill argue that the National Labor Relations Act as it has evolved and been interpreted by the courts and the NLRB has lost its effectiveness in protecting the rights of individuals seeking to form a union as well as those who are union members and seek to redress unfair labor practices committed by employers. In support of the legislation, Representative George Miller (D-A) Chairman of the House Committee on Education and Labor stated that:

The current process for forming unions is badly broken and so skewed in favor of those who oppose unions that workers must literally risk their jobs in order to form a union. Although it is illegal, one-quarter of employers facing an organizing drive have been found to fire at least one worker who supports a union. In fact, employees who are active union supporters have a one-in-five chance of being fired for legal activities. Sadly, many employers resort to spying, threats, intimidation, harassment, and other illegal activity in their campaigns to oppose unions. 
The penalty for illegal activity including firing workers for engaging in protected activities is so weak it does little to deter law breakers.

Even when employers don't break the law, the process itself stacks the deck against union supporters. The employer has all the power; they control the information workers can receive, can force workers to attend anti-union meetings during work hours, can force workers to meet with supervisors who deliver anti-union messages, and can imply the business will close if the union wins. Union supporters' access to employees, on the other hand, is heavily restricted. (3)

Addressing the difficulties unions have in organizing and the obstacles that employers place in the way of such organizations, Kate Bronfenbrenner of Cornell University, after studying hundreds of union organizing campaigns, found that:

(1) Ninety-two percent of private sector employers, when faced with employees who want to form together in a union, force employees to attend closed-door meetings to hear antiunion propaganda, 80 percent require supervisors to attend training sessions on attacking unions and 78 percent required that supervisors deliver antiunion messages to workers they oversee.

(2) Seventy-five percent hire outside consultants to run antiunion campaigns, often based on mass psychology and distorting the law.

(3) Half of employers threaten to shut down partially or totally if employees join together in a union.

(4) In 25 percent of organizing campaigns private sector employers illegally fire workers because they want to form a union.

(5) Even after workers successfully form a union, in one-third of the instances, employers do not want to negotiate a contract.(4)

In addition to framing their support of the legislation in terms of facilitating union organizing, proponents of the legislation see the law's impact, if enacted, as far beyond the rights of workers seeking to unionize. Proponents view the importance of the law as a means of strengthening middle class workers whether union or nonunion. . Representative Robert Andrews, D-NJ, addressing this issue stated that:

For the past six years, middle class workers have seen their wages and benefits shrink even as corporate profits and executive compensation have soared. The reality is that workers in unions earn 30 percent more in wages than non-union workers and 80 percent of union workers have health insurance while only 49 percent of nonunion workers do. Coercive employers determined to obstruct any efforts to allow workers to organize, have eroded the basic underpinnings of middle class life: decent wages and benefits.(5) .

As stated previously, Congressional hearings were held on the bill on February 8, 2007 and March 27, 2007. The hearing on February 8, 2007 was conducted by the House Subcommittee on Health, Employment, Labor and Pensions. The hearing on March 27, 2007 was conducted by the Senate Committee on Health, Education, Labor and Pensions.

Persons appeared before both committees in support of and against the Bill. Supporters of the Bill focused on the inadequacies of the National Labor Relations Act as it is presently written and applied as well as addressing the spillover effect that obstacles to union organizing have had on reducing work place benefits for the middle class, whether union or non-union. Specifically: (1) middle class incomes have not kept pace with or ahead of inflation as far as wages are concerned (2) there has been a decline in the number of employees covered by health insurance benefits (3) as well as a decline in pension benefits for employees.

Cynthia L. Esland, Professor of Law at New York University, has addressed the need to reform the law in the following terms:

Congress has not revisited the core of the National Labor Relations Act (N.L.R.A,) since 1947, when President Truman was in office, the U.S. economy and its manufacturing base were unrivaled, and nearly on-third of the work 
force was represented by unions. Much has changed. The System is now severely broken and it needs fixing. . One of the basic issues she raises is the inadequacy of remedies available to workers who have been fired or discriminated against for actively trying to form a union. On the issue of discrimination against employees for union activities, she raises the question: What does the law do about it? Her answer to the question is framed in the following terms:

Of course, the law does nothing unless Board officials can prove a discriminatory motive on the part of the employer who creates and controls nearly all relevant documents and employs nearly all of the relevant witnesses. Even if these hurdles are overcome and the employee is found to have been illegally discharged, often years after the discharge, the employee may be granted reinstatement (rarely implemented where years have gone by) and back pay (minus any wages the employee has received or should have received, in the meantime, in many cases, that amounts to almost nothing. The employee does not get traditional compensation or punitive damages, and no fines are assessed. In the meantime, the damage to the organizing efforts had long been done, and the law does nothing to repair that.

When comparing these remedies to what is available under other federal antidiscrimination statutes, one can only conclude that the law doesn't regard anti-union discrimination, a violation of federal law, as all that bad.

One study of the U.S. labor laws for a major international human rights organization concluded, (Many employers realize that they have little to fear from labor law enforcement through a ponderous delay riddled legal system with meager remedial powers.) The law's palid response to illegality has led many employers to regard legal sanctions as a "routine" cost of doing business well worth it to get rid of organizing leaders and derail workers' organizing efforts. As a result, a culture of near-impunity has taken shape in much labor law and practice." (7)

Another issue addressed in the Congressional hearings is the fact that even if the union wins the election, such a victory is no assurance that a collective bargaining relationship will be established.

Nancy Schiffer, Associate General Counsel for the AFL-CIO, in her testimony on February 8, 2007 before the House Subcommittee on Health, Employment, Labor and Pensions stated that:

Even when workers are able to form their union, they were not able to bargain a first contract. Out of 1,586 initial contract bargaining cases closed by the Federal Mediation and Conciliation Service (FMCS) during 2004, 710 (45\%) of the total were closed without a contract being reached. According to the NLRB General Counsel Ronald Meisburg, meritorious NLRB charges alleging illegal refusal to bargain by employers are filed in 28 percent of all newly certified bargaining relationships. Of all NLRB charges alleging refusal to bargain by employers, half occur in first contract bargaining. What is the remedy when an employer engages in unlawful bargaining tactics? The employer is ordered to bargain some more. (8)

Incentives for not bargaining in good faith exist because of the following:

Anti-union consultants and Union-avoidance" specialists know that the employer's anti-union campaign does not end when the Board certifies the union as the worker's representative. These consultants and specialists typically offer their services through the entire bargaining process. If they can continue the campaign of fear and intimidation and not reach a contract for a year they are rewarded with another opportunity to eliminate the union. If no contract is concluded in twelve months, the N.L.R.B. will conduct another election. So the strategy for remaining union-free includes stalling contract negotiations, frustrating collective bargaining and fomenting disillusionment and a feeling of futility. (9)

\section{MAJORITY SIGN UP}

To replace the current election system whereby unions and employers respectively campaign for and against union representation of the employees, the Employee Free Choice Act provides for the certification of a union when a majority of workers sign authorization cards expressing their decision to form a union for collective 
bargaining. Under current law, recognition by a majority-sign up is available to unions only if the employer agrees to this procedure as an alternative to the secret ballot election process.

So called "neutrality agreements" have been negotiated with a limited number of companies -Singular- the largest wireless carrier in the nation, accepted a "neutrality agreement" with the Communication Workers of America. (C.W.A.) Kaiser-Permanente, Alcoa, and others also have neutrality agreements

"Majority Sign-up" is available to public sector workers. The states of California, New York, New Jersey and Illinois now provide majority sign-up for their public sector workers.

Under current law, the employer has the right to veto this decision of a majority of the workers. In fact, even if every single worker in the union wants to form a union to bargain a contract, the employer has no obligation whatsoever to recognize their union and bargain. (10)

\section{ARGUMENTS AGAINST THE BILL}

One main criticism of the Bill is the absence of a secret ballot process. Authorization cards, which potential members would sign to express their desire to unionize, are the critics argue not in the interest of workers. Critics of the proposed legislation cite the fact that the vote would not be confidential, whereas, under the existing

law the union member's vote is confidential. These opponents say the absence of a secret ballot process with respect to the signing of the authorization card would subject workers to peer pressure, harassment, coercion, and misrepresentation. The Heritage Foundation, a conservative research organization, has argued that the proposed Employee Free Union Act, if enacted, would:

(1) Hinder worker voting rights: Rather than holding a secret ballot election, the EFCA would institute a card check system, creating a union if a majority of workers submitted cards requesting that one be created. These cards would not protect the identity of the signers, making clear who was in favor and who was against the creation of a union.

(2) Leave workers vulnerable to intimidation; by removing the secret ballot system, the union and the employers would be aware of which employees wanted to create a union and which ones did not. This would pave the way for intimidation efforts from both unions and employers.

(3) Give unions an unfair advantage in negotiations with employers: because the card signing drives are put together by union organizations, employees would be given a one-sided pitch and put into a high pressure signing situation. (11)

Included in the Employee Free Choice Act is a provision for first-contract mediation and arbitration if the parties cannot come to an agreement.

Peter J. Hurtgen, Senior Partner, Morgan, Lewis and Bockius, in a statement before the Senate Committee on Labor on March 27, 2007 argued against the Employee Free Choice Act's provisions for interest arbitration in the following terms:

In addition to mandating recognition by card check rather than secret ballot election, the Act would eviscerate another fundamental tenet of U.S. labor law: voluntary agreement.

No outside agency, whether arbitration, courts or government has the skill, knowledge, or expertise to create a collective bargaining agreement. If it is not a creature of the parties' creation, it likely will fail of its purpose. The negotiation of a collective bargaining agreement is the search for mutually resolving each side's interests. It must be done with tradeoffs and separate prioritizing. Only the parties can do that, there are no standards for arbitrators to apply. There is no skill set for arbitrators to use. Solomon is simply unavailable. (12) 


\section{ECONOMIC AND SOCIAL ISSUES AND THE EMPLOYEE FREE CHOICE ACT}

Proponents of the Employee Free Choice Act argue that the difficulties unions face when trying to organize workers and the decline of unions impacts on all sectors of the middle class whether union or non-union.

Larry Mishel, President of the Economic Policy Institute, testifying before the Senate Committee on Labor on March 27, 2007, asserted that at stake in the passage of the legislation is the promotion of racial, sexual and national origin equality. On this issue he asserts that:

When one compares workers whose experience, education, region, industry, occupation and marital status are comparable, those covered by union agreement enjoy:

$14.7 \%$ higher wages

$28.2 \%$ more likely to have employer-provided health insurance

$53.9 \%$ more likely to have pension coverage

$14.3 \%$ more paid time off

The union wage premiums vary by race, ethnicity and gender, but are large for every group:

$\begin{array}{ll}\text { Whites } & 13.1 \% \\ \text { Blacks } & 20.3 \% \\ \text { Hispanics } & 21.9 \% \\ \text { Asians } & 16.7 \% \\ \text { Men } & 18.4 \% \\ \text { Women } & 10.5 \%(13)\end{array}$

Mishel, in his statement before the Senate Committee, also discussed larger economic issues, including the issue of the effect of unions have on competitiveness. Addressing the issue of competitiveness, Mishel asserts that decades of research shows that unions can have substantial positive effects on performance. At least four factors account for the positive impact on performance:

1. Unions give employees a voice in the work place allowing them to complain, shape operations, and push for change, rather than simply quitting or being fired.

2. Union employees feel freer to speak up about operations, leading to improvements that increase productivity. Employment security fuels collaboration and information sharing, leading to higher productivity.

3. Higher pay pushes employers to find other ways to lower costs with new technology, increased investment and better management.

4. Union employees get more training, both because they demand it and because management is willing to invest more to get a return on their higher pay. (14)

Harley Shaiken, a professor at the University of California-Berkeley, who testified before the House Labor Committee on February 8, 2007, stated that:

The economics literature indicates that unionization and high productivity often go hand-in-hand. Fairness on the job and wages that reflect marketplace success contribute to more motivated workers. Bolman points out that unions, (provide opportunities for firms to better their performance.) Without unions, day-to-day competitive pressures leave workers with quitting as the only option to address serious problems, a costly solution for all concerned. Given the pressures of globalization and competitiveness today, unions have been responsive to increasing productivity and embracing new methods. (15) 


\section{THE PRODUCTIVITY-PAY GAP}

Both Mishel and Shaiken, address a disturbing economic trend in the United States, the disconnect between productivity and pay. Mishel asserts that:

I have shown that the decline in union representation has been a major cause of two disturbing trends in our economy: the rise in inequality and the failure of average working Americans to share the benefits of rising productivity. (16)

Addressing this same issue, Shaiken observes that:

We are living through a period that might be best termed, the "Great Disconnect" since the economy is growing and wages are flattening. The good news is that productivity expanded by a healthy 20 percent between 2000 and 2006; the bad news is that most of this has bypassed workers. Real wages, Larry Mishel tells us, whether we are talking about a median worker or a college graduate will have edged up about 2 percent as a spillover from the late 1990s. Between 1996, and 2001 only the top 10\% of taxpayers scored an increase in real labor income per-hour that kept up with productivity growth according to economists Jan Dew Becker and Robert J. Gerber. The bottom 90 percent of the income distribution fell behind or was even left out of productivity gains entirely. While life has been good at the top, more recently it has become absolutely regal at the very top. Dew Becker and Gordon Ford found that "the top one-tenth of one percent of the income distribution earned as much of the real 1997-2001 gain in wage and salary income as the bottom 50 percent. This income distribution is so extreme that even the top one percent feels they are among the dispossessed. It is hardly a surprise that the Economist magazine noted in the summer 2006 issue that growth is fast, unemployment is low and profits are fat. [Yet] only one in four Americans believe the economy is in good shape. While firms' profits have soared, wages for the typical worker here hardly budged.(17)

\section{CONCLUSION AND OBSERVATIONS}

The Employee Free Choice Act, as presently formulated, addresses significant problems facing individuals seeking to organize a union, enter into a collective bargaining agreement after the union is organized and provides meaningful penalties for employers who violate workers' rights.

With respect to the issue of first contract mediation and arbitration, the evidence is clear that unions need to have a means to ensure the negotiation and implementation of a first contract after the union wins the election. In the absence of the parties coming to an agreement, mediation and arbitration are a well-tested means of impasse resolution in labor relations.

With respect to the issue of providing adequate protections for workers attempting to form a union, the law has proven to be, in its effectiveness, woefully inadequate. The remedies presently available under the National Labor Relations Act have proved to be woefully inadequate to deter employers from illegal conduct.

On the issue of certification on the basis of majority sign-up the laws' provisions, if enacted, would replace a broken system with a potentially unworkable one.

If the Employee Free Choice Act becomes law, the following are valid criticisms that those who are opposed to the law have asserted:

(1) In an N.L.R.B. supervised election, workers' rights must be posted by the employer three days before the election. With card checks, workers rights are explained by a union organizer.

(2) When N.L.R.B. supervised elections occur, there can be no captive audience speeches within 24 hours of the election. With card checks, workers can be subjected to pro-union speeches even while signing the cards. 
(3) N.L.R.B. elections have observers selected by management and labor. With card checks, union employees secure workers signatures.

(4) In elections, the ballot box is inspected and sealed by the N.L.R.B. With card checks, union organizers control the actual cards.

(5) On cards the signers' names appear. In elections, no workers' names or other identification appear on the ballots. (18)

In view of the past experience with the present election procedure, simplification of the procedure is essential to increase fairness in the process. The Bill, as presently written, provides that "it would require the Board to develop authorization language and procedures for establishing the validity of signed authorizations." The N.L.R.B. procedures set forth above could be applied to union certification on the basis of majority sign-up based on authorization cards. As set forth above, the card itself could be the secret ballot. However, the signing of, or refusal to, sign the card and the protection of the democratic process would be preserved by the N.L.R.B. procedures set forth above.

The evidence is strong that all middle class workers, whether union or non-union, whether white collar or professional employees have suffered because of a decline in union representation. Pensions and health care benefits, as well as other basic standards of employment from the decades of the1950-1970s, became standard fringe benefits for nonunion employees as well as union employees, in large part because of the impact of unionization. Unfortunately, for all working Americans below the higher echelons in the work force, such standards have been significantly eroded as is evidenced by the increasing rareness of defined benefit pension plans and a continuing erosion of the scope of health benefits for all workers. Thus, the framers of the Employee Free Choice Act are correct in asserting that the enactment of the legislation is not merely a concern of traditional union workers. The economic evidence is clear that the middle class is not progressing or, at best, is making very small strides economically and that making sure that employees who want to unionize can do so is important for all working Americans.

The proposed EFCA provisions for first contract mediation and arbitration when the parties can not come to agreement are important and necessary protections for workers wanting union representation. The proposed Act's provision for stricter penalties on employers for violations of worker's rights is much needed to protect worker's rights to form and be represented by unions.

\section{AUTHOR INFORMATION}

Dr. Richard Trotter is an Associate Professor of Management at the University of Baltimore who received a B.S. from Columbia University, an M.A. and Ph.D. from the University of Pennsylvania and an J.D. from Rutgers University. He is a member of the Pennsylvania Bar and is admitted to practice before the United States Supreme Court.

Dr. Trotter's research interests include various facets of employment law and labor relations. In addition to teaching and research, Dr. Trotter is a Labor Arbitrator who has arbitrated extensively in the private and public sectors on a wide range of issues.

\section{ENDNOTES}

(1) The Employee Free Choice Act, http://www.enwikipedia.org/wiki/Employee FreeChoiceAct

(2) Employee Free Choice Act_Congress pedia http://www.sourcewatch.org/index.php?title=Employee FreeChoice_Act pp.2-3

(3) Employee Free Choice Act: http://enwikipedia.org/wikipedia.org/wiki/Employee Free Choce Act p. 2-3

(4) The System For Forming Unions is Broken http://www.aflcio.org/joinaunion/voiceatwork/efca/broken system.cfm

(5) Robert Andrews Statement at Hearing on "Strengthening America's Middle Class Through the Employee Free Choice Act" http://www.house.gov/appslist/speech/ed labor_demandrews Statement Feb. htm/ 
(6) Testimony of Cynthia L. Estland, Catherine A. Rein, Professor of Law, New York University School of Law, before the Senate Committee on Health, Education, Labor, and Pensions, March 27, 2007 (help: senate.gov.) link_hearing, March 27, 2007, p. 1

(7) Ibid. pp. 2-3

(8) Testimony of Nancy Schiffer, Associate General Counsel for the AFL-CIO, February 8, 2007, testimony before the House Committee on Health, Employment, Labor, and Pensions,

edlabor.house.gov.tab.hearing.year-February 8, 2007

(9) Ibid. pp. 7-8

(10) Ibid. Schiffer p. 8

(11) Employee Free Choice Act - Congresspedia, http://www.source watch.org/index.php?title=EmployeeFree-Act pp. 7-8.

(12) Statement of Peter J. Hurtgen, Senior Partner, Morgan, Lewis and Bokius, LLP, March 27, 2007, help.senate.gov.link hearing year March 2007 pp. 14-15

(13) Larry Mishel, "The Right to Organize, Freedom and the Middle Class Squeeze," Testimony before the Senate Committee on Health, Education, Labor and Pensions, U.S. Senate help.senate.gov.link_hearing year March 27, 2007 p. 3.

(14) Ibid, p. 4

(15) Harley Shaiken, Testimony, House of Representatives, Subcommittee on Health, Employment, Labor and Pensions, "Strengthening America's Middle Class Through the Employee Free Choice Act" February 8, 2007, edlabor.house.gov. tab hearing year February 8,2007, p. 6

(16) Mishel Ibid. at note 16, p. 6

(17) Shaiken Ibid. at note 18, p. 2

(18) Viewpoint-Employee Free Choice Act puts A Target on the Back of Manufacturers http:// :www.industry week.com/Read Article.aspx?Article ID=12867 


\section{NOTES}

